\title{
Floristic analysis of the Mountain Zebra National Park, Eastern Cape
}

\author{
U. Pond, B.B. Beesley，L.R. Brown \& H. Bezuidenhout
}

Pond, U., B.B. Beesley, L.R. Brown \& H. Bezuidenhout. 2002. Floristic analysis of the Mountain Zebra National Park, Eastern Cape. Koedoe 45(1): 35-57. Pretoria. ISSN 0075-6458.

As part of a larger project to assess the vegetation dynamics and conservation potential of the enlarged Mountain Zebra National Park, a checklist was produced to determine the plant species richness for this area. Six hundred and eighty species, represented by 333 genera and 87 families were identified. One hundred and eighty species belong to the Monocotyledoneae and 479 species to the Dicotyledoneae. By far the largest families are the Asteraceae with 129 and the Poaceae with 82 species. Thirteen Red Data species were recorded. A number of fynbos elements were encountered, the most noteworthy being two families endemic to the Cape Floristic Region, the Penaeaceae and Grubbiaceae. A very high species to square kilometre ratio of 5.05 supports the area's rich floristic composition.

Key words: Floristic analysis, species richness, plant species list, Mountain Zebra National Park.

U. Pond, B.B. Beesley, L.R. Brown $\square$, Applied Natural Sciences, Technikon SA, Private Bag X6, Florida 1710, South Africa; H. Bezuidenhout, Conservation Development, South African National Parks, P O Box 110040, Hadison Park, Kimberley 8306, South Africa.

\section{Introduction}

The Mountain Zebra National Park (MZNP) was proclaimed a protected area in 1937 (Wahl \& Naude 1996). It is situated in a zone transitional between the Nama Karoo Biome in the west and the Grassland Biome in the east (Hoffman 1998), but classified as being part of the Nama Karoo (Low \& Rebelo 1998). The primary objective for this park is to conserve a viable, genetically uncontaminated, representative population of the Cape Mountain Zebra Equus zebra zebra. Secondary objectives are the conservation of a representative spectrum of the typical faunal elements under natural conditions, and secodly, vegetation types that are unique to this region (Van der Walt 1980).

In 1996, a process was initiated to incorporate adjacent farmland into the park. This will increase the park's area substantially, from the original 6536 ha to approximately 18000 ha (Brown \& Bezuidenhout 2000), once current negotiations have been completed. Two extensive vegetation studies have been conducted: a phytosociological reconnaissance of the original MZNP by Van der Walt (1980); and a phytosociological account, describing and mapping the plant communities of the newly acquired De Rust section of the MZNP (Brown \& Bezuidenhout 2000). As part of a larger and long-term research project, the latter study aimed at assessing the habitat suitability to establish large herbivores on the new farms.

No annotated comprehensive plant species list of MZNP is available. Surveys of the floristic diversity and species richness of an area are fundamental to any wildlife management programme and conservation policy. A floristic database of an area serves as a permanent reference to establish site uniqueness and species richness, monitoring changes in species occurrence and the distribution of endemic and Red Data species. This study set out to provide a floristic checklist for the 


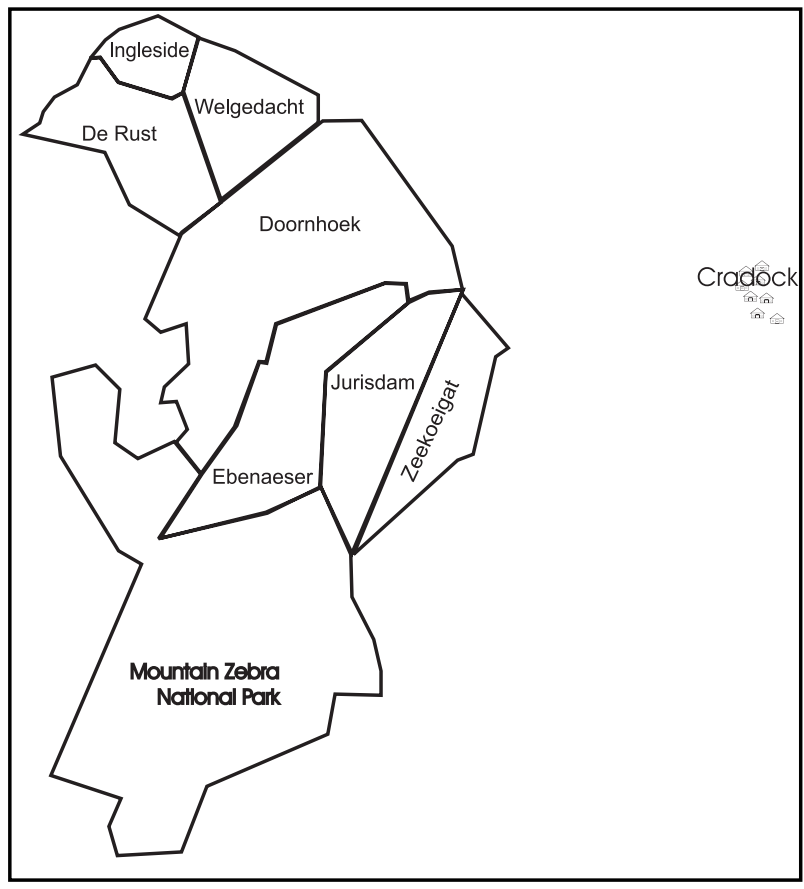

(Bankberg

$1927 \mathrm{~m}$

and

Rooiplaat $1360 \mathrm{~m}$ above sea level. The Wilgerboom River traverses the central valley of the southern section and exits the park at $1200 \mathrm{~m}$ a.s.l. to the north. The northwest (De Rust) is dominated by Salpeterkop (1514 m a.s.1.), a typical mesa of the Karoo landscape with a steep gradient. This gives way to a mid-slope plateau, footslopes and an undulating plain with seasonally dry river beds towards the eastern and central part of the park, at approximately $1000 \mathrm{~m}$ above sea level. The heterogeneous vegetation is co-dominated by dwarf shrubs and grasses, with patches of incipient forest in drainage lines and the extensive grass plain of Rooiplaat.

Figure 1. Location of the study area.

MZNP including the newly acquired farms De Rust, Doornhoek and Welgedacht.

\section{Study area}

\section{Location}

The MZNP is found in the Eastern Cape Province, situated 24 kilometres west of Cradock. The area under discussion extends from $32^{\circ} 06^{\prime} 50^{\prime \prime}-32^{\circ} 18^{\prime} 50^{\prime \prime} \mathrm{S}$ and $25^{\circ} 24^{\prime} 00^{\prime \prime}-$ $25^{\circ} 30^{\prime} 00^{\prime \prime} \mathrm{E}$ and includes the former MZNP (6 536 ha), De Rust (1 712 ha), Doornhoek (4 $027 \mathrm{ha}$ ) and Welgedacht (1 $189 \mathrm{ha}$ ).

\section{Topography}

The southern parts of the MZNP are characterised by mountainous terrain with steepsided drainage lines from mountaintops

\section{Climate}

The mean rainfall for the area is $382 \mathrm{~mm}$ per annum (1962-1998), ranging from the highest rainfall of $651 \mathrm{~mm}$ (1977) to the lowest rainfall of $153 \mathrm{~mm}$ (1966), as measured at the MZNP weather station. The rainy season occurs mostly in late summer and autumn, and the winters are relatively dry. Mean monthly minimum and maximum temperatures vary from $6-28^{\circ} \mathrm{C}$ in summer (September-March) and from $0-20{ }^{\circ} \mathrm{C}$ during winter (April- August) (Brown \& Bezuidenhout 2000). Extreme temperatures range from $-7^{\circ} \mathrm{C}$ to $37^{\circ} \mathrm{C}$ and severe frost is likely during the period May-October (Van der Walt 1980). Van der Walt (1980), further states that the vegetation is subjected to continuous climatic variables due to the influence of an arid climate from the east and a more moderate climate from the west. The southern mountainous peaks are exposed to increased cloud cover, extreme temperature and moisture regimes, with local climate variations resulting in a number of microhabitats. Bankberg forms a barrier to cold winter fronts, thus a warmer climate is experienced in the sheltered val- 
ley below whilst regular snowfall occurs on higher lying areas (Van der Walt 1980).

\section{Geology and soil}

Mudstone, sandstone and shale of the Beaufort Group of the Karoo Supergroup dominate the MZNP (Keyzer 1997). These mudstones and shales are relatively unstable and subject to mechanical and chemical weathering. The material derived from these processes is usually rich in clay and salts. In addition, the MZNP sediments have been penetrated on a large scale by Post-Karoo dolerite intrusions (Keyzer 1997), forming large sheets and a number of dykes. The southern part of the park is characterised by dolerite outcrops that are remnants of the former sheet, of which the resistant Bankberg is a prominent feature (Van der Walt 1980). Highly fertile clayey soils are also derived from the fairly resistant doleritic parent material. Calcareous bedrock (limestone) lines some river courses (pers.obs.), formed by chemical precipitation from sandstone or mudstone and found in tributaries of the Wilgerboom River from Kranskop peak (Brown \& Bezuidenhout 2000).

\section{Methods}

Plant collections were undertaken over a two-year period during 1999 and 2000. The areas covered included De Rust, Doornhoek, Welgedacht and the following areas within the former MZNP: Rooiplaat, Kranskop, the top of Bankberg and along the kloofs down to Weltevrede and Fonteinkloof. Collection sites were selected randomly within the extensive area according to topography and plant phenology, ensuring that all variations in habitat were considered and sampled. All specimens were labelled, pressed and dried, then identified by the Selmar Schönland Herbarium in Grahamstown and form part of the collection of the Kimberley South African National Parks Herbarium. Selected duplicates are kept at the Selmar Schönland Herbarium and Technikon SA.

The final species list was compiled from various sources: Pond and Beesley's collection, van der Walt (1980) and a species list supplied by PRECIS (National Herbarium Pretoria Computerised Infor- mation System) for the MZNP. Plant names were entered into and consolidated by SaS (2002), a database for the Cape and Karoo floras. While Arnold \& De Wet (1993) served as a basis for nomenclature and arrangement, $\mathrm{SaS}$ introduced the latest taxonomic changes and appropriate author updates. Only identified species were listed. Red Data status, also produced by SaS, follows Hilton-Taylor (1996). Introduced species were included and are followed by an asterisk $(*)$.

\section{Results}

The MZNP plant species list totals 680 species, which represent 333 genera and 87 families. Flowering plants are represented by Monocotyledoneae with 180 species in 14 families $(16 \%$ of the total number of families) and Dicotyledoneae with 479 species in 62 families $(71 \%)$. The Bryophytes with seven families $(8 \%)$ and the Pteridophytes with four families $(5 \%)$ represent non-flowering plants (Fig. 2). The complete species list, separated into the different plant divisions, sorted by family and indicating the species' Red Data status where applicable, appears as Appendix 1. This study added 100 new species to previous records for the MZNP. Introduced species were included in all floristic calculations.

The MZNP flora is represented by 87 families, as reflected in Table 1.

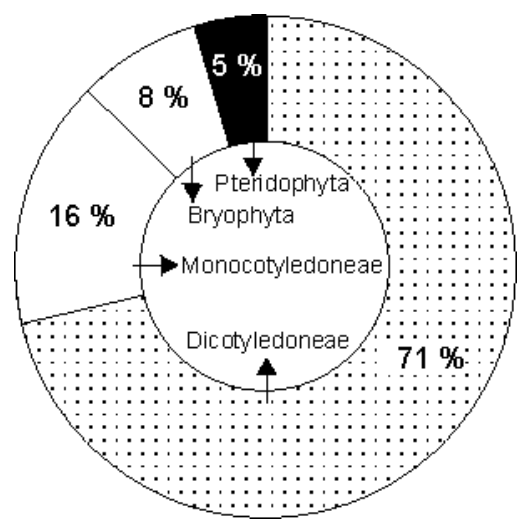

Fig. 2. Plant divisions reflected as a percentage of the total number of plant families. 
Table 1

An alphabetical list of plant families collected in the MZNP, indicating the number of genera and species in each family

\begin{tabular}{|c|c|c|c|c|c|}
\hline Families & Genera & Species & Families & Genera & Species \\
\hline \multicolumn{3}{|l|}{ BRYOPHYTES } & Commelinaceae & 2 & 2 \\
\hline \multirow{8}{*}{$\begin{array}{l}\text { Aytoniaceae } \\
\text { Bryaceae } \\
\text { Fissidentaceae } \\
\text { Grimmiaceae } \\
\text { Pottiaceae } \\
\text { Ptychomitriaceae } \\
\text { Ricciaceae }\end{array}$} & \multirow[b]{2}{*}{1} & \multirow{2}{*}{1} & Convolvulaceae & 3 & 3 \\
\hline & & & Crassulaceae & 2 & 18 \\
\hline & 1 & 1 & Cucurbitaceae & 2 & 3 \\
\hline & 1 & 1 & Dipsacaceae & 1 & 2 \\
\hline & 2 & 2 & Ebenaceae & 2 & 5 \\
\hline & 2 & 2 & Ericaceae & 1 & 5 \\
\hline & 1 & 1 & Euphorbiaceae & 2 & 10 \\
\hline & 1 & 2 & Fabaceae & 13 & 35 \\
\hline \multicolumn{3}{|l|}{ PTERIDOPHYTES } & Gentianaceae & 2 & 2 \\
\hline & & & Geraniaceae & 4 & 21 \\
\hline Anemiaceae & 1 & 1 & Grubbiaceae & 1 & 1 \\
\hline Aspleniaceae & 1 & 2 & Haloragaceae & 1 & 1 \\
\hline Equisetaceae & 1 & 1 & Kiggelariaceae & 1 & 1 \\
\hline Pteridaceae & 2 & 7 & Lamiaceae & 7 & 13 \\
\hline \multirow{2}{*}{\multicolumn{3}{|c|}{ MONOCOTYLEDONEAE }} & Linaceae & 1 & 1 \\
\hline & & & Loranthaceae & 1 & 1 \\
\hline Alliaceae & 1 & 1 & Malvaceae & 5 & 15 \\
\hline Amaryllidaceae & 5 & 9 & Melianthaceae & 1 & 1 \\
\hline Asparagaceae & 1 & 12 & Mesembryanthemac. & 10 & 22 \\
\hline Asphodelaceae & 5 & 13 & Molluginaceae & 3 & 3 \\
\hline Commelinaceae & 2 & 3 & Myrsinaceae & 2 & 2 \\
\hline Convallariaceae & 2 & 2 & Nyctaginaceae & 1 & 1 \\
\hline Cyperaceae & 9 & 18 & Oleaceae & 1 & 1 \\
\hline Hyacinthaceae & 7 & 17 & Orobanchaceae & 1 & 1 \\
\hline Hypoxidaceae & 2 & 3 & Oxalidaceae & 1 & 5 \\
\hline Iridaceae & 8 & 12 & Papaveraceae & 2 & 2 \\
\hline Juncaceae & 1 & 6 & Pedaliaceae & 2 & 2 \\
\hline Poaceae & 47 & 82 & Penaeaceae & 1 & 2 \\
\hline Potamogetonaceae & 1 & 1 & Plantaginaceae & 1 & 1 \\
\hline Tecophilaeaceae & 1 & 1 & Polygalaceae & 2 & 6 \\
\hline \multirow{2}{*}{\multicolumn{3}{|c|}{ DICOTYLEDONEAE }} & Polygonaceae & 2 & 2 \\
\hline & & & Portulacaceae & 1 & 1 \\
\hline Acanthaceae & 2 & 3 & Ranunculaceae & 3 & 3 \\
\hline Aizoaceae & 3 & 6 & Rhamnaceae & 1 & 1 \\
\hline Amaranthaceae & 5 & 10 & Rosaceae & 1 & 1 \\
\hline Anacardiaceae & 2 & 9 & Rubiaceae & 4 & 5 \\
\hline Apiaceae & 6 & 6 & Salicaceae & 2 & 2 \\
\hline Apocynaceae & 12 & 14 & Santalaceae & 1 & 1 \\
\hline Araliaceae & 1 & 1 & Sapindaceae & 1 & 1 \\
\hline Asteraceae & 51 & 129 & Scrophulariaceae & 10 & 31 \\
\hline Bignoniaceae & 1 & 1 & Solanaceae & 5 & 12 \\
\hline Boraginaceae & 3 & 4 & Thymelaceae & 2 & 3 \\
\hline Brassicaceae & 10 & 13 & Urticaceae & 1 & 2 \\
\hline Buddlejaceae & 2 & 3 & Verbenaceae & 4 & 4 \\
\hline Campanulaceae & 3 & 12 & Viscaceae & 1 & 2 \\
\hline Caryophyllaceae & 3 & 4 & Vitaceae & 2 & 2 \\
\hline \multirow[t]{2}{*}{ Celastraceae } & 2 & 4 & Zygophyllaceae & 2 & 2 \\
\hline & & & TOTAL & 87 & 680 \\
\hline
\end{tabular}




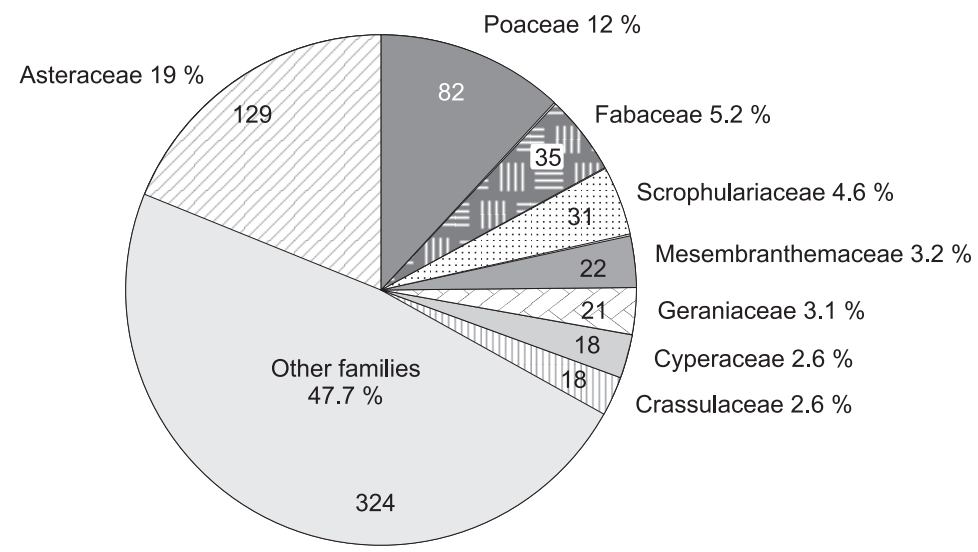

Fig. 3. Dominant plant families reflecting the number of species and percentage of the total flora

Eight families dominate the MZNP flora. By far the two largest families are the Asteraceae with 129 species, reflecting $19 \%$ of the total flora and the Poaceae with 82 species $(12 \%)$. These are followed by much smaller, yet significant families, represented by the Fabaceae with 35 species $(5.2 \%)$, Scrophulariaceae 31 (4.6\%), Mesembryanthemaceae $22(3.2 \%)$, Geraniaceae 21 $(3.1 \%)$, Cyperaceae $18(2.6 \%)$ and the Crassulaceae also with 18 species and $2.6 \%$ of the species total (Fig. 3). These eight fam- ilies represent $52.3 \%$ of the MZNP flora, while the other 79 families reflect the remaining $47.7 \%$.

Twenty-nine genera are represented by five or more species. These are listed in Table 2.

Thirteen Red Data species were found, representing $1.9 \%$ of the MZNP flora (Fig. 4). Red Data species and the categorisation are indicated in the species list (Appendix 1). Symbols and terms used in Appendix 1:

Table 2

Dominant genera and number of species per genus

\begin{tabular}{lclc}
\hline Genus & No of species & Genus & No of species \\
\hline Helichrysum & 20 & Juncus & 6 \\
Senecio & 17 & Lotononis & 6 \\
Pelargonium & 17 & Delosperma & 6 \\
Crassula & 14 & Cheilanthes & 6 \\
Asparagus & 12 & Oxalis & 5 \\
Euryops & 9 & Polygala & 5 \\
Euphorbia & 9 & Pentzia & 5 \\
Selago & 9 & Pteronia & 5 \\
Eragrostis & 8 & Erica & 5 \\
Rhus & 8 & Lessertia & 5 \\
Wahlenbergia & 8 & Felicia & 5 \\
Indigofera & 7 & Ornithogalum & 5 \\
Hermannia & 7 & Stachys & 5 \\
Jamesbrittania & 7 & Aristida & 5 \\
\hline
\end{tabular}


Introduced species $(*)$ amount to $46(6.7 \%)$ (Appendix 1). The majority of these belong to the Poaceae, represented by the genera: Bromus, Chloris, Eleusine, Eragrostis, Hordeum, Melinis, Paspalum, Poa, Polypogon, Setaria, Tragus, Vulpia; Amaranthaceae: Alternanthera, Atriplex, Chenopodium, Salsola; Asteraceae: Anthemis, Bidens, Cirsium, Lactuca, Schkuhria, Verbesina; Brassicaceae: Capsella, Cardaria, Descurainia, Sisymbrium; Caryophyllaceae: Stellaria; Convolvulaceae: Cuscuta; Malvaceae: Malva; Papaveraceae: Argemone; Plantaginaceae: Plantago; Anacardiaceae: Schinus; Apiaceae: Ammis, Ciclospermum; Cyperaceae: Cyperus; Polygonaceae: Polygonum; Salicaceae: Populus; Solanaceae: Datura, Nicotiana; Urticaceae: Urtica; Verbenaceae: Verbena.

\section{Discussion}

The Mountain Zebra National Park boasts 680 species, 333 genera and 87 families. This contrasts with the low plant species diversity for the Nama Karoo claimed by Hall, (1980) some 20 years ago. Other Nama Karoo floras compare as follows: Augrabies Falls National Park with 364 species, Karoo National Park (822), Karoo Nature Reserve (320) and of the Succulent Karoo: Goegap
Nature Reserve (550), Richtersveld National Park (537) and Tankwa Karoo National Park with 245 species ( $\mathrm{SaS} 2002)$ (Table 3).

As illustrated in Fig. 3, the high presence of Asteraceae (19\%) corresponds with most floras of the sub-region and it is usually the largest family in floras of arid to semi-arid regions (Goldblatt \& Manning 2000). The graminoids are strongly represented by the Poaceae $(12 \%)$. Rutherford \& Westfall (1986) remark that hemicryptophytes of the Nama Karoo Biome are mainly C4 grasses, which are adapted to high temperatures and low water supply. This is relative, as the Eastern Mixed Nama Karoo has the highest rainfall of all the Karoo types and is thus ecotonal to grassland (Hoffman 1998). The relatively high proportion of Fabaceae $(5.2 \%)$ is not exceptional, as this family is well developed in most parts of the world. So is the wealth of Scrophulariaceae $(4.6 \%)$, which is reflected right across Africa, especially in the floras of drier areas (Goldblatt \& Manning 2000).

There is a gradient of species replacement within the dry Karoo from winter to summer rainfall. For example, the Mesembryanthemaceae, represented by $3.2 \%$ in the MZNP, ranked amongst the dominant families. However, the Mesembryanthemaeceae decline from the west (the centre of

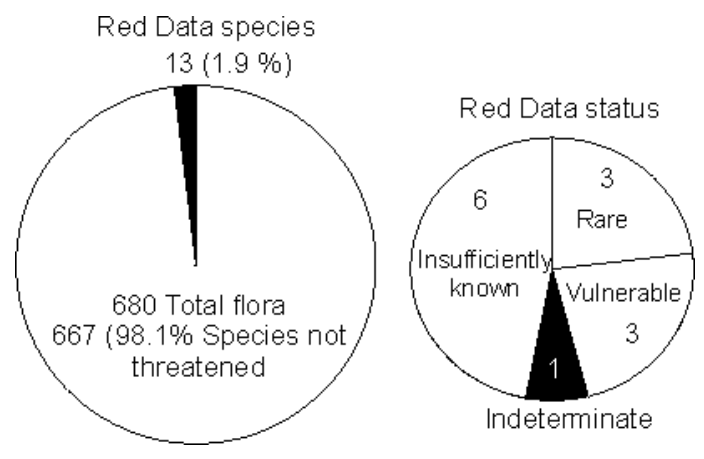

Fig. 4. Number and status of Red Data species according to Hilton-Taylor (1996). 
endemism and species radiation) to the east, where they are replaced by other groups, such as the Crassulaceae, which make up $2.6 \%$ of the MZNP flora.

Of the 87 plant families, $71 \%$ are Dicotyledoneae and $16 \%$ Monocotyledoneae (Fig. 2). Monocoteae are generally herbaceous, whereas dicots are woody or herbaceous and in general much more diverse in habitat (Jones \& Luchsinger, 1987), suggesting that they are also accustomed to greater edaphic and climatic variations. A ratio of 3.8 dicots to 1 monocot species for the MZNP is slightly higher than that of the Cape floristic region and the average for floras across the world at 3:1 (Goldblatt \& Manning 2000). Although less diverse in habitat, monocot families have specialised to co-dominate in most floras of the sub-region. Graminoids, such as Restionaceae, Poaceae and Cyperaceae are respectively ranked as the $8^{\text {th }}, 11^{\text {th }}$ and $12^{\text {th }}$ largest families of the Cape flora (Goldblatt \& Manning 2000). Whilst the Restionaceae depend on winter rainfall and are less prominent east of the Cape Floral Kingdom, the Poaceae emerge in the more arid summer rainfall areas and rate as the $2^{\text {nd }}$ largest family in the MZNP (12\% of the total flora). Hoffman \& Cowling (1987) noted that an overall increase in grass cover from west to east correlated with an overall increase in rainfall and a decline in winter rainfall. The Cyperaceae (generally associated with impoverished sandstone soils of the Cape mountain ranges by Goldblatt \& Manning, (2000) amount to $2.6 \%$ of the flora (18 species) in the Mountain Zebra National Park.

Red Data species make up $1.9 \%$ of the MZNP flora (Fig. 4; Appendix 1), which is low compared to Fynbos, for example, which displays an average of 3-7\% of Red Data species. Other Karoo floras, however, also display low numbers of Red Data species, e.g., Augrabies Falls National Park with $0.6 \%$, Karoo National Park $2.2 \%$, Karoo Nature Reserve 1.6 \%, Tankwa Karoo National Park 2.4\%, Goegap Nature Reserve $2.4 \%$. Richtersveld National Park has a contrasting high of $6 \%$ (Sas 2002).
Hall et al. (1980), also found the number of rare and endangered species for the Nama Karoo biome to be low.

A unique feature of MZNP is the occurrence of two families that are endemic to fynbos, i.e., the Penaeaceae and Grubbiaceae. Whilst Penaea cneorum has been recorded from the Kogelberg and Riviersonderend Mountains to Port Elizabeth, Penaea acutifolia is a new record, previously only recorded from the Outeniqua Mountains to George. Also, Grubbia rosmarinifolia, whose current range of distribution is restricted from the Koue Bokkeveld to the Tsitsikamma Mountains (Goldblatt \& Manning 2000), is a fynbos element and has been recorded in the park.

Apart from the two records above, a number of fynbos elements were found in the park. According to Low (A.B. Low, P O Box 370, Rondebosch, 7701) (pers. comm. 2000), locally occurring genera, such as Eriocephalus, Elytropappus, Euryops, Maytenus and Diospyros are normally associated with Renosterveld (on shale), while Passerina, Erica and Gnidia as well as the Amaryllidaceae are also associated with Fynbos. Passerina and Dodonaea spp. are known to link summer and winter rainfall areas. In addition, arid Fynbos is normally characterised by the absence of Ericaceae, and yet, here it is found in the more arid Karoo. To the same extent, Leucosidea sericea that commonly occurs in Drakensberg streams has also been recorded in the Mountain Zebra National Park.

The floristic region of southern Africa (Botswana, Lesotho, Namibia, South Africa and Swaziland) has about 20400 native vascular plant species in an area of $2674000 \mathrm{~km}^{2}$. South Africa alone may have some 18500 species of these, considered a particularly rich and diverse flora for a predominantly temperate region. The Cape Floristic Region (CFR) at $90000 \mathrm{~km}^{2}$, with 9000 species, is striking by world standards (Goldblatt \& Manning 2000). At a smaller scale, however, the MZNP study area (13 464 ha of the entire 18000 ha) and other Karoo floras were compared in Table 3 
Table 3

Comparison of the species/area ratio of selected protected areas in South Africa

\begin{tabular}{lccc}
\hline Area & Size (ha) & Number of species & Species per 100 ha \\
\hline Augrabies Falls National Park & 18600 & 364 & 1.95 \\
Goegap Nature Reserve & 14531 & 550 & 3.78 \\
Kalahari Gemsbok National Park & 959300 & 489 & 0.05 \\
Karoo National Park & 43261 & 822 & 1.90 \\
Karoo Nature Reserve & 16000 & 320 & 2.00 \\
Mountain Zebra National Park & 13464 & 680 & 5.05 \\
Richtersveld National Park & 162445 & 537 & 0.33 \\
Tankwa Karoo National Park & 27064 & 245 & 0.90 \\
Vaalbos National Park & 22696 & 334 & 1.47 \\
\hline
\end{tabular}

(Zietsman \& Bezuidenhout 1999; Zietsman et al. 1992; Van Rooyen \& Bezuidenhout 1997; SaS 2002).

Plant species richness at 5.05 species per 100 ha is considerably higher when compared to the other parks and reserves. Thus the MZNP displays a rich floristic composition, a result of extreme habitat and substrate diversity, ranging from sandstones to shales and dolerite dykes to calcareous bedrock with extensive grass plains, shrublands, high altitude seeps and riverine thicket. Microclimatic conditions play an important role in the germination and establishment of seedlings of karoo plants (Roux \& Theron 1987).

Geophytes seem best adapted to a seasonally extreme climate with a wet winter and dry summer, in semi-arid conditions (Goldblatt \& Manning 2000). This is evident in the Succulent Karoo, where geophytes are most abundant, both in terms of species richness and cover (Hoffman \& Cowling 1987). There is a high incidence of geophytes in the MZNP ( $8 \%$ of the total flora) represented by the Alliaceae, Amaryllidaceae, Asphodelaceae, Hyacinthaceae, Hypoxydaceae and Iridaceae. Despite the fact that most of the park experiences a semi-arid climate with erratic rainfall that occurs mainly in summer, Hoffman \& Cowling (1987) remark that geophytes are very conspicuous in the eastern Karoo.

\section{Conclusion}

The Eastern Mixed Nama Karoo comprises of $77784 \mathrm{~km}^{2}$, of which only $1.08 \%$ is presently conserved (Low \& Rebelo 1998). Complex soils, erratic rainfall and climate, as well as variations in altitude and habitat have driven the processes leading to a relatively high species richness for the Mountain Zebra National Park. It is clear that vegetation is much more than a list of plant species. This floristic account, together with the studies on plant communities (Van der Walt 1980; Brown \& Bezuidenhout 2000), serves as a basis to develop a habitat management plan for the national park. Considered an ecotone between the Nama Karoo and Grassland Biomes, this area displays a rich variety of vegetation types and habitats in juxtaposition. The results of this study indicate that the newly enlarged Mountain Zebra National Park forms an important conservation area and is a noteworthy centre of biological diversity, including species richness, ecosystem complexity and genetic variation. It is therefore important that a detailed management plan be developed for the park to ensure the sustainalbe utilisation and conservation of the vegetation of the area.

\section{Acknowledgements}

The following individuals and institutions are sincerely thanked: South African National Parks (SANParks) and Technikon SA (TSA) for initiating this 
study; National Research Foundation (NRF) and Technikon SA for financing this study; National Botanical Institute for the use of data from the National Herbarium, Pretoria (PRE) Computerised Information System (PRECIS) and for ad hoc identifications; Tony Dold at the Selmar Schönland Herbarium, Grahamstown for plant identifications; Barrie Low, Environmental Consultant, for the input and update of the species list via the SaS database and for comment on the draft report; Johan de Klerk, Section Game Ranger at MZNP, for his help and support; Mountain Zebra National Park warden Paddy Gordon (at the time) and staff for accommodating this study.

\section{References}

ACOCKS, J.P.H. 1988. Veld Types of South Africa. 3rd edn. Memoirs of the Botanical Survey of South Africa 57: 1-146.

ARnOLD, T.H. \& B.C. DE WET. 1993. Plants of southern Africa: names and distribution. Memoirs of the Botanical Survey of South Africa 62: 5-825.

BRown, L.R. \& H. BezuidenHout. 2000. The phytosociology of the De Rust section of the Mountain Zebra National Park, Eastern Cape. Koedoe 43(1): 1-18.

Goldblatt, P. \& J. Manning. 2000. Cape Plants. A conspectus of the Cape Flora of South Africa. Strelitzia 9. Cape Town: Missouri Botanical Gardens USA \& National Botanical Institute, SA.

Hall, A.V., M. DE Winter, B. DE Winter \& S.A.M. Oosterhout. 1980. Description of Biomes. Pp. 45-65. In: Rutherford, M.C. \& R.H. Westfall. Biomes of Southern Africa - an objective categorization. Pretoria: Botanical Research Institute, Department of Agriculture and Water Supply. (Memoirs of the Botanical Survey of South Africa; no 54.)

Hilton-TAYlor, C. 1996. Red Data List of Southern African Plants. Strelitzia 4. Cape Town: Conservation Biology Research Unit, National Botanical Institute.

Hoffman, T. 1998. Eastern Mixed Nama Karoo. P. 55. In: Low, A.B. \& A.G. Rebelo (eds.) 1998. Vegetation of South Africa, Lesotho and Swaziland. Pretoria: Department of Environmental Affairs and Tourism.

HoffMAn, M.T. \& R.M. Cowling. 1987. Plant physiognomy, phenology and demography. Pp. 1-34. In: Cowling, R.M. \& P.W. Roux (eds.). The karoo biome: a preliminary synthesis. Part $2-$ vegetation and history. Pretoria: Council for Scientific and Industrial Research, National Scientific Programmes Unit. (South African National Scientific Programmes report; no 142).

Jones, S.B. \& A.E. Luchsinger. 1987. Plant Systematics. 2nd ed. Singapore: McGraw-Hill.

KeYZER, N. 1997. Geological Map of the Republic of South Africa and Kingdoms of Lesotho and Swaziland, 1:1 000 000. Pretoria: Council for Geoscience.

Low, A.B. \& A.G. Rebelo. (eds.) 1998. Vegetation of South Africa, Lesotho and Swaziland. Pretoria: Department of Environmental Affairs and Tourism.

Roux, P.W. \& G.K. Theron. 1987. Vegetation change in the Karoo Biome. Pp. 50-69. In: Cowling, R.M. \& P.W. Roux (eds.). The karoo biome: a preliminary synthesis. Part 2 - vegetation and history. Pretoria: Council for Scientific and Industrial Research, National Scientific Programmes Unit. (South African National Scientific Programmes report; no 142).

RUTHERFoRd, M.C. \& R.H. WestFall. 1986. Biomes of Southern Africa - an objective categorization. Pretoria: Botanical Research Institute, Department of Agriculture and Water Supply. (Memoirs of the Botanical Survey of South Africa; no. 54.)

SAS. 2002. Site and Species database for the Cape and Karoo Floras. Rondebosch: Coastec.

VAN DER WALT, P.T. 1980. A phytosociological reconnaissance of the Mountain Zebra National Park. Koedoe 23: 1-32.

Van Rooyen, N. \& H. Bezuidenhout. 1997. New records of flowering plants and ferns from the Kalahari Gemsbok National Park. Koedoe 40(2): 105-116.

WaHL, M. \& K. NAUdE. 1996. National register of protected areas in South Africa. Pretoria: Department of Environmental Affairs and Tourism.

Zietsman, P.C. \& H. Bezuidenhout. 1999. Flowering plant biodiversity of Augrabies Falls National Park: a comparison between Augrabies Falls National Park, Kalahari Gemsbok National Park, Vaalbos National Park and Goegap Nature Reserve. Koedoe 42(2): 95-112.

Zietsman, P.C., P.J. Du Preez \& H. Bezuidenhout. 1992. A preliminary check list of flowering plants of the Vaalbos National Park. Koedoe 35(1): 89-98.

Appendix 1

Plant species list for the Mountain Zebra National Park

Appendix 1 .../ 
E Endangered - taxa in danger of extinction if causal factors continue operating

Ex Extinct - taxa which are no longer known to exist in the wild

I Indeterminate -taxa known to be extinct, endangered, vulnerable or rare but information is insufficient to categorise them

$\mathrm{K}$ Insufficiently known -taxa that are suspected to belong to any of the above categories but information is lacking

R Rare - taxa with small world populations, presently not endangered or vulnerable but at risk that a threat could cause a critical decline

$\mathrm{V}$ Vulnerable -taxa believed likely to move into the endangered category in the near future if the factors causing decline continue operating

Us Unspecified -taxa previously threatened but are no longer in any of the above categories due to an increase in population size or to subsequent discoveries

* Introduced species

Family

Species

Red Data

Pres/Past

\section{BRYOPHYTES}

$\begin{array}{ll}\text { AYTONIACEAE } & \text { Plagiochasma rupestre var. rupestre (G.Forst.) Steph. } \\ \text { BRYACEAE } & \text { Bryum turbinatum } \text { (Hedw.) Turner } \\ \text { FISSIDENTACEAE } & \text { Fissidens rufescens } \text { Hornsch. } \\ \text { GRIMMIACEAE } & \text { Grimmia pulvinata } \text { (Hedw.) Sm. } \\ \text { GRIMMIACEAE } & \text { Schistidium apocarpum } \text { (Hedw.) Bruch \& Schimp. } \\ \text { POTTIACEAE } & \text { Microbryum davallianum } \text { (Sm.) R.H.Zander } \\ \text { POTTIACEAE } & \text { Triquetrella tristicha } \text { (C.Müll.) C.Müll. } \\ \text { PTYCHOMITRIACEAE } & \text { Ptychomitrium subcrispatum Thér. \& P.Vard. } \\ \text { RICCIACEAE } & \text { Riccia nigrella } \text { DC. } \\ \text { RICCIACEAE } & \text { Riccia simii Perold }\end{array}$

Complete list

Selective list

\begin{tabular}{llll}
\hline Total species: & 680 & Total species: & 10 \\
Total genera: & 333 & Total genera: & 9 \\
\hline Total families: & 87 & Total families: & 7 \\
Total red data species: & 13 & Total red data species: & 0
\end{tabular}

\section{PTERIDOPHYTES}

ANEMIACEAE

ASPLENIACEAE

ASPLENIACEAE

EQUISETACEAE

PTERIDACEAE

PTERIDACEAE

PTERIDACEAE

PTERIDACEAE

PTERIDACEAE

PTERIDACEAE

PTERIDACEAE

Complete list
Mohria vestita Baker

Asplenium cordatum (Thunb.) Sw.

Asplenium trichomanes $\mathrm{L}$.

Equisetum ramosissimum Desf.

Cheilanthes bergiana Schlechtd.

Cheilanthes eckloniana (Kunze) Mett.

Cheilanthes hirta Sw.

Cheilanthes induta Kunze

Cheilanthes multifida (Sw.) Sw. subsp. multifida

Cheilanthes parviloba (Sw.) Sw.

Pellaea calomelanos (Sw.) Link var. calomelanos 


\section{MONOCOTYLEDONEAE}

ALLIACEAE

AMARYLLIDACEAE AMARYLLIDACEAE AMARYLLIDACEAE AMARYLLIDACEAE AMARYLLIDACEAE AMARYLLIDACEAE AMARYLLIDACEAE AMARYLLIDACEAE AMARYLLIDACEAE ASPARAGACEAE ASPARAGACEAE ASPARAGACEAE ASPARAGACEAE ASPARAGACEAE ASPARAGACEAE ASPARAGACEAE ASPARAGACEAE ASPARAGACEAE ASPARAGACEAE ASPARAGACEAE ASPARAGACEAE ASPHODELACEAE ASPHODELACEAE ASPHODELACEAE ASPHODELACEAE ASPHODELACEAE ASPHODELACEAE ASPHODELACEAE ASPHODELACEAE ASPHODELACEAE ASPHODELACEAE ASPHODELACEAE ASPHODELACEAE ASPHODELACEAE COMMELINACEAE COMMELINACEAE COMMELINACEAE CONVALLARIACEAE CONVALLARIACEAE CYPERACEAE CYPERACEAE CYPERACEAE CYPERACEAE CYPERACEAE CYPERACEAE CYPERACEAE CYPERACEAE CYPERACEAE
Tulbaghia galpinii Schltr.

Ammocharis coranica (Ker Gawl.) Herb.

Boophone disticha (L.f.) Herb.

Cyrtanthus contractus N.E.Br.

Cyrtanthus macowanii Baker

Cyrtanthus spiralis Burch. ex Ker Gawl.

Us

Cyrtanthus suaveolens Schönland

$\mathrm{V}$

K

Haemanthus albiflos Jacq.

Haemanthus humilis subsp. humilis Jacq.

Nerine huttoniae Schönland

K

Asparagus capensis var. capensis L.

Asparagus cooperi Baker

Asparagus densiflorus (Kunth) Jessop

Asparagus denudatus (Kunth) Baker

Asparagus exuvialis Burch. forma exuvialis

Asparagus glaucus Kies

Asparagus mucronatus Jessop

Asparagus multiflorus Baker

Asparagus retrofractus $\mathrm{L}$.

Asparagus striatus (L.f.) Thunb.

Asparagus suaveolens Burch.

Aloe striata Haw. subsp. striata

Aloe striatula Haw. var. caesia Reynolds

Aloe variegata $\mathrm{L}$.

Bulbine abyssinica A.Rich.

Bulbine frutescens (L.) Willd.

Bulbine narcissifolia Salm-Dyck

Gasteria bicolor Haw. var. bicolor

Haworthia arachnoidea (L.) Duval

Haworthia deltoidea (Hook.f.) Parr var. deltoidea

Haworthia herbacea (Mill.) Stearn var. herbacea

Haworthia lockwoodii Archibald

$\mathrm{V}$

Kniphofia acraea Codd

$\mathrm{R}$

Kniphofia uvaria (L.) Oken

Commelina africana L. var. africana

Commelina africana L. var. lancispatha C.B.Clarke

Cyanotis speciosa (L.f.) Hassk.

Eriospermum corymbosum Baker

Sansevieria aethiopica Thunb.

Bulbostylis humilis (Kunth) C.B.Clarke

Carex spicato-paniculata C.B.Clarke

Cyperus denudatus L.f

Cyperus laevigatus $\mathrm{L}$.

Cyperus rotundus $\mathrm{L}$.

Cyperus usitatus Burch.

Fuirena coerulescens Steud.

Isolepis costata (Boeck.) A.Rich. var. costata

Isolepis karroica (C.B.Clarke) J.Raynal 
CYPERACEAE

CYPERACEAE

CYPERACEAE

CYPERACEAE

CYPERACEAE

CYPERACEAE

CYPERACEAE

CYPERACEAE

CYPERACEAE

HYACINTHACEAE

HYACINTHACEAE

HYACINTHACEAE

HYACINTHACEAE

HYACINTHACEAE

HYACINTHACEAE

HYACINTHACEAE

HYACINTHACEAE

HYACINTHACEAE

HYACINTHACEAE

HYACINTHACEAE

HYACINTHACEAE

HYACINTHACEAE

HYACINTHACEAE

HYACINTHACEAE

HYACINTHACEAE

HYACINTHACEAE

HYPOXIDACEAE

HYPOXIDACEAE

HYPOXIDACEAE

IRIDACEAE

IRIDACEAE

IRIDACEAE

IRIDACEAE

IRIDACEAE

IRIDACEAE

IRIDACEAE

IRIDACEAE

IRIDACEAE

IRIDACEAE

IRIDACEAE

IRIDACEAE

JUNCACEAE

JUNCACEAE

JUNCACEAE

JUNCACEAE

JUNCACEAE

JUNCACEAE

POACEAE

POACEAE

POACEAE

POACEAE

POACEAE

POACEAE

POACEAE

POACEAE
Isolepis setacea (L.) R. Br.

Kyllinga alata Nees

Kyllinga alba Nees

Kyllinga pulchella Kunth

Mariscus congestus (Vahl) C.B.Clarke

Mariscus sumatrensis (Retz.) J. Raynal

Mariscus uitenhagensis Steud.

Pseudoschoenus inanis (Thunb.) Oteng-Yeboah

Schoenoxiphium sparteum (Wahlenb.) C.B.Clarke

Albuca flaccida Jacq.

Albuca maxima Burm.f.

Albuca shawii Baker

Dipcadi ciliare (Zeyh. ex Harv.) Baker

Eucomis comosa (Houtt.) H.R.Wehrh. var. comosa

Lachenalia karooica W.F.Barker ex G.D.Duncan

Lachenalia variegata W.F.Barker

Ledebouria apertiflora (Baker) Jessop

Ledebouria cooperi (Hook.f.) Jessop

Ledebouria undulata (Jacq.) Jessop

Massonia echinata L.f.

Massonia pustulata Jacq.

Ornithogalum graminifolium Thunb.

Ornithogalum juncifolium Jacq.

Ornithogalum maculatum Jacq.

Ornithogalum paludosum Baker

Ornithogalum secundum Jacq.

Empodium plicatum (Thunb.) Garside

Hypoxis angustifolia Lam. var. angustifolia

Hypoxis argentea var. argentea Harv. ex Baker

Dierama pendulum (L.f.) Baker

Gladiolus permeabilis D.Delaroche

subsp. edulis (Burch. ex Ker Gawl.) Oberm.

Hesperantha longituba (Klatt) Baker

Lapeirousia plicata (Jacq.) Diels subsp. plicata

Moraea elliotii Baker

Moraea polystachya (Thunb.) Ker Gawl.

Moraea simulans Baker

Romulea atrandra G.J.Lewis var. atrandra

Syringodea concolor (Baker) M.P.de Vos

Tritonia dubia Eckl. ex Klatt

Tritonia laxifolia Benth. ex Baker

Tritonia lineata (Salisb.) Ker Gawl.

Juncus dregeanus Kunth

Juncus effusus L.

Juncus oxycarpus E.Mey. ex Kunth

Juncus exsertus Buchenau subsp. exsertus

Juncus inflexus L.

Juncus rigidus Desf.

Agrostis lachnantha Nees var. lachnantha

Aristida adscensionis L.

Aristida congesta Roem. \& Schult. subsp. congesta

Aristida diffusa Trin. subsp. burkei (Stapf) Meld.

Aristida diffusa Trin. subsp. diffusa

Aristida junciformis Trin. \& Rupr.

Bothriochloa radicans (Lehm.) A.Camus

Bromus catharticus Vahl 
POACEAE

POACEAE

POACEAE

POACEAE

POACEAE

POACEAE

POACEAE

POACEAE

POACEAE

POACEAE

POACEAE

POACEAE

POACEAE

POACEAE

POACEAE

POACEAE

POACEAE

POACEAE

POACEAE

POACEAE

POACEAE

POACEAE

POACEAE

POACEAE

POACEAE

POACEAE

POACEAE

POACEAE

POACEAE

POACEAE

POACEAE

POACEAE

POACEAE

POACEAE

POACEAE

POACEAE

POACEAE

POACEAE

POACEAE

POACEAE

POACEAE

POACEAE

POACEAE

POACEAE

POACEAE

POACEAE

POACEAE

POACEAE

POACEAE

POACEAE

POACEAE

POACEAE

POACEAE

POACEAE

POACEAE

POACEAE
Bromus pectinatus Thunb.

Cenchrus ciliaris L.

Chloris virgata $\mathrm{Sw}$.

Cymbopogon dieterlenii Stapf ex E.Phillips

Cymbopogon marginatus (Steud.) Stapf ex Burtt Davy

Cymbopogon plurinodis (Stapf) Stapf ex Burtt Davy

Cynodon dactylon (L.) Pers.

Cynodon incompletus Nees

Digitaria eriantha Steud.

Diplachne fusca (L.) P.Beauv. ex Roem. \& Schult.

Ehrharta calycina J.E.Sm. var. calycina

Ehrharta erecta Lam. var. erecta

Eleusine coracana (L.) Gaertn.

Elionurus muticus (Spreng.) Kunth

Enneapogon scoparius Stapf

Eragrostis barrelieri Daveau

Eragrostis bergiana (Kunth) Trin.

Eragrostis chapelieri (Kunth) Nees

Eragrostis chloromelas Steud.

Eragrostis curvula (Schrad.) Nees

Eragrostis lehmanniana Nees var. lehmanniana

Eragrostis obtusa Munro ex Ficalho \& Hiern

Eragrostis plana Nees

Eustachys paspaloides (Vahl) Lanza \& Mattei

Festuca scabra Vahl

Fingerhuthia africana Lehm.

Fingerhuthia sesleriiformis Nees

Helictotrichon capense Schweick.

Heteropogon contortus (L.) P.Beauv. ex Roem. \& Schult.

Hordeum stenostachys Godr.

Hyparrhenia hirta (L.) Stapf

Koeleria capensis (Steud.) Nees

Melica decumbens Thunb.

Melica racemosa Thunb.

Melinis nerviglumis (Franch.) Zizka

Melinis repens (Willd.) Ziska

Merxmuellera disticha (Nees) Conert

Merxmuellera stricta (Schrad.) Conert

Microchloa caffra Nees

Miscanthus capensis (Nees) Andersson

Oropetium capense Stapf

Panicum coloratum L. var. coloratum

Panicum deustum Thunb.

Panicum maximum Jacq.

Panicum stapfianum Fourc.

Paspalum dilatatum Poir.

Pennisetum macrourum Trin.

Pennisetum sphacelatum (Nees) T.Durand \& Schinz

Pentaschistis airoides (Nees) Stapf subsp. airoides

Pentaschistis airoides (Nees) Stapf subsp. jugorum (Stapf) H.P.Linder

Pentaschistis curvifolia (Schrad.) Stapf

Pentaschistis glandulosa (Schrad.) H.P.Linder

Phragmites australis (Cav.) Trin. ex Steud.

Poa annua L.

Polypogon monspeliensis (L.) Desf.

Schismus barbatus (Loefl. ex L.) Thell. 
POACEAE

POACEAE

POACEAE

POACEAE

POACEAE

POACEAE

POACEAE

POACEAE

POACEAE

POACEAE

POACEAE

POACEAE

POACEAE

POACEAE

POACEAE

POACEAE

POACEAE

POACEAE

POTAMOGETONACEAE

TECOPHILAEACEAE
Schismus inermis (Stapf) C.E.Hubb.

Setaria nigrirostris (Nees) T.Durand \& Schinz

Setaria sphacelata (Schum.) Stapf \& C.E.Hubb. ex Moss

var. sphacelata

Setaria verticillata (L.) P.Beauv.

Sporobolus africanus (Poir.) Robyns \& Tournay

Sporobolus discosporus Nees

Sporobolus fimbriatus (Trin.) Nees

Stipa dregeana Steud. var. dregeana

Stipa dregeana Steud. var. elongata (Nees) Stapf

Stipagrostis ciliata (Desf.) De Winter

Stipagrostis obtusa (Del.) Nees

Tetrachne dregei Nees

Themeda triandra Forssk.

Tragus berteronianus Schult.

Tragus koelerioides Aschers.

Tribolium hispidum (Thunb.) Desv.

Urochloa panicoides P.Beauv.

Vulpia myuros (L.) C.C.Gmel.

Potamogeton pusillus L.

Cyanella lutea L.f.

Complete list

Selective list

\begin{tabular}{llcc}
\hline Total species: & 680 & Total species: & 180 \\
Total genera: & 333 & Total genera: & 92 \\
Total families: & 87 & Total families: & 14 \\
Total red data species: & 13 & Total red data species: & 5
\end{tabular}

\section{DICOTYLEDONEAE}

ACANTHACEAE

ACANTHACEAE

ACANTHACEAE

AIZOACEAE

AIZOACEAE

AIZOACEAE

AIZOACEAE

AIZOACEAE

AIZOACEAE

AMARANTHACEAE

AMARANTHACEAE

AMARANTHACEAE

AMARANTHACEAE

AMARANTHACEAE

AMARANTHACEAE

AMARANTHACEAE

AMARANTHACEAE

AMARANTHACEAE

AMARANTHACEAE

ANACARDIACEAE

ANACARDIACEAE

ANACARDIACEAE

ANACARDIACEAE

ANACARDIACEAE
Blepharis capensis var. capensis (L.f.) Pers.

Blepharis villosa (Nees) C.B.Clarke

Justicia orchioides L.f. subsp. glabrata Immelman

Aizoon glinoides L.f.

Galenia africana L.

Galenia procumbens L.f.

Galenia pubescens var. pubescens (Eckl. \& Zeyh.) Druce

Galenia sarcophylla Fenzl

Tetragonia echinata Aiton

Alternanthera pungens H.B.\&K.

Atriplex semibaccata R.Br.

Atriplex suberecta I.Verd.

Atriplex vestita (Thunb.) Aellen

Chenopodium mucronatum Thunb.

Chenopodium murale L.

Chenopodium schraderianum Roem. \& Schult.

Salsola aphylla L.f.

Salsola kali $\mathrm{L}$.

Suaeda fruticosa (L.) Forssk.

Rhus divaricata Eckl. \& Zeyh.

Rhus dregeana Sond.

Rhus erosa Thunb.

Rhus gracillima Engl.

Rhus lancea L.f. 
ANACARDIACEAE ANACARDIACEAE ANACARDIACEAE ANACARDIACEAE APIACEAE

APIACEAE

APIACEAE

APIACEAE

APIACEAE

APIACEAE

APOCYNACEAE

APOCYNACEAE

APOCYNACEAE

APOCYNACEAE

APOCYNACEAE

APOCYNACEAE

APOCYNACEAE

APOCYNACEAE

APOCYNACEAE

APOCYNACEAE

APOCYNACEAE

APOCYNACEAE

APOCYNACEAE

APOCYNACEAE

ARALIACEAE

ASTERACEAE

ASTERACEAE

ASTERACEAE

ASTERACEAE

ASTERACEAE

ASTERACEAE

ASTERACEAE

ASTERACEAE

ASTERACEAE

ASTERACEAE

ASTERACEAE

ASTERACEAE

ASTERACEAE

ASTERACEAE

ASTERACEAE

ASTERACEAE

ASTERACEAE

ASTERACEAE

ASTERACEAE

ASTERACEAE

ASTERACEAE

ASTERACEAE

ASTERACEAE

ASTERACEAE

ASTERACEAE

ASTERACEAE

ASTERACEAE

ASTERACEAE

ASTERACEAE

ASTERACEAE

ASTERACEAE
Rhus lucida $\mathrm{L}$.

Rhus pyroides Burch var. pyroides.

Rhus undulata Jacq.

Schinus molle L.

Ammis majus L. var. glaucifolium (L.) Godron

Berula erecta (Huds.) Coville subsp. thunbergii (DC.) B.L.Burtt

Bupleurum mundii Cham. \& Schlechtd.

Ciclospermum leptophyllum (Pers.) Sprague

Deverra burchellii (DC.) Eckl. \& Zeyh.

Heteromorpha arborescens (Spreng.) Cham. \& Schltdl.

Asclepias compressidens (N.E.Br.) A.Nicholas

Brachystelma circinatum E.Mey.

Carissa haematocarpa (Eckl.) A.DC.

Duvalia caespitosa (Masson) Haw. var. caespitosa

Duvalia modesta N.E.Br.

Gomphocarpus fruticosa $\mathrm{L}$.

Gomphocarpus tomentosus Burch.

Huernia brevirostris N.E.Br. subsp. intermedia N.E.Br.

Microloma armatum (Thunb.) Schltr. ex Gilg var. armatum

Pachycymbium miscellum (N.E.Br.) M.Gilbert

Pachypodium succulentum (L.f.) A.DC.

Sarcostemma viminale (L.) R.Br. subsp. viminale

Schizoglossum aschersonianum Schltr. var. aschersonianum

Stenostelma capense Schltr.

Cussonia paniculata Eckl. \& Zeyh. subsp. paniculata

Amellus strigosus (Thunb.) Less.

Anthemis cotula L.

Arctotheca calendula (L.) Levyns

Arctotis arctotoides (L.f.) O.Hoffm.

Arctotis microcephala (DC.) P.Beauv.

Berkheya armata (Vahl) Druce

Berkheya decurrens (Thunb.) Willd.

Bidens pilosa $\mathrm{L}$.

Chrysanthemoides monilifera (L.) Norl. subsp. subcanescens (DC.) Norl.

Chrysocoma ciliata $\mathrm{L}$.

Cineraria aspera Thunb.

Cineraria geraniifolia DC.

Cineraria lobata L'Her.

Cirsium vulgare (Savi) Ten.

Conyza podocephala DC.

Conyza scabrida DC.

Cotula heterocarpa DC.

Cotula nigellifolia (DC.) Bremer \& Humphries

Cotula zeyheri Fenzl

Cuspidia cernua (L.f.) B.L.Burtt

Dimorphotheca cuneata (Thunb.) Less.

Dimorphotheca zeyheri Sond.

Elytropappus rhinocerotis (L.f.) Less.

Eriocephalus africanus L.

Eriocephalus ericoides (L.f.) Druce

Eriocephalus eximius DC.

Eriocephalus punctulatus DC.

Euryops annae E.Phillips

Euryops annuus Compton

Euryops anthemoides B.Nord. subsp. anthemoides

Euryops dentatus B.Nord. 
ASTERACEAE

ASTERACEAE

ASTERACEAE

ASTERACEAE

ASTERACEAE

ASTERACEAE

ASTERACEAE

ASTERACEAE

ASTERACEAE

ASTERACEAE

ASTERACEAE

ASTERACEAE

ASTERACEAE

ASTERACEAE

ASTERACEAE

ASTERACEAE

ASTERACEAE

ASTERACEAE

ASTERACEAE

ASTERACEAE

ASTERACEAE

ASTERACEAE

ASTERACEAE

ASTERACEAE

ASTERACEAE

ASTERACEAE

ASTERACEAE

ASTERACEAE

ASTERACEAE

ASTERACEAE

ASTERACEAE

ASTERACEAE

ASTERACEAE

ASTERACEAE

ASTERACEAE

ASTERACEAE

ASTERACEAE

ASTERACEAE

ASTERACEAE

ASTERACEAE

ASTERACEAE

ASTERACEAE

ASTERACEAE

ASTERACEAE

ASTERACEAE

ASTERACEAE

ASTERACEAE

ASTERACEAE

ASTERACEAE

ASTERACEAE

ASTERACEAE

ASTERACEAE

ASTERACEAE

ASTERACEAE

ASTERACEAE

ASTERACEAE
Euryops floribundus N.E.Br.

Euryops lateriflorus (L.f.) DC.

Euryops oligoglossus DC. subsp. oligoglossus

Euryops spathaceus DC.

Euryops tenuissimus (L.) DC.

Felicia fascicularis DC.

Felicia filifolia (Vent.) Burtt Davy subsp. filifolia

Felicia muricata (Thunb.) Nees subsp. muricata

Felicia ovata (Thunb.) Compton

Felicia zeyheri (Less.) Nees subsp. linifolia (Harv.) Grau

Foveolina albida (DC.) Kallersjo

Garuleum bipinnatum (Thunb.) Less.

Garuleum pinnatifidum (Thunb.) DC.

Gazania krebsiana Less. subsp. arctotoides (Less.) Roessler

Gazania krebsiana Less. subsp. krebsiana

Gazania linearis (Thunb.) Druce

Geigeria ornativa O.Hoffm.

Gymnostephium papposum Nesom

Helichrysum anomalum Less.

Helichrysum asperum (Thunb.) Hilliard \& B.L.Burtt var. asperum

Helichrysum cerastioides DC. var. cerastioides

Helichrysum dasycephalum O.Hoffm.

Helichrysum dregeanum Sond. \& Harv.

Helichrysum epapposum Bolus

Helichrysum hamulosum E.Mey. ex DC.

Helichrysum lineatum Bolus

Helichrysum lucilioides Less.

Helichrysum montanum DC.

Helichrysum nudifolium (L.) Less.

Helichrysum odoratissimum (L.) Sweet

Helichrysum petiolare Hilliard \& B.L.Burtt

Helichrysum rosum (Berg.) Less. var. rosum

Helichrysum rugulosum Less.

Helichrysum rutilans (L.) D.Don

Helichrysum splendidum (Thunb.) Less.

Helichrysum trilineatum DC.

Helichrysum umbraculigerum Less.

Helichrysum zeyheri Less.

Hertia pallens (DC.) Kuntze

Ifloga glomerata (Harv.) Schltr.

Kleinia longiflora DC.

Lactuca inermis Forssk.

Lasiopogon muscoides (Desf.) DC.

Lasiospermum bipinnatum (Thunb.) Druce

Lasiospermum pedunculare Lag.

Marasmodes polycephalus DC.

Mikania cordata (Burm.f.) B.L.Rob.

Oldenburgia paradoxa Less.

Oligocarpus calendulaceus (L.f.) Less.

Oncosiphon piluliferum (L.f.) Kallersjo

Othonna auriculifolia Licht. ex Less.

Othonna cylindrica (Lam.) DC.

Othonna pavonia E.Mey.

Pegolettia retrofracta (Thunb.) Kies

Pentzia cooperi Harv.

Pentzia globosa Less. 
ASTERACEAE

ASTERACEAE

ASTERACEAE

ASTERACEAE

ASTERACEAE

ASTERACEAE

ASTERACEAE

ASTERACEAE

ASTERACEAE

ASTERACEAE

ASTERACEAE

ASTERACEAE

ASTERACEAE

ASTERACEAE

ASTERACEAE

ASTERACEAE

ASTERACEAE

ASTERACEAE

ASTERACEAE

ASTERACEAE

ASTERACEAE

ASTERACEAE

ASTERACEAE

ASTERACEAE

ASTERACEAE

ASTERACEAE

ASTERACEAE

ASTERACEAE

ASTERACEAE

ASTERACEAE

ASTERACEAE

ASTERACEAE

ASTERACEAE

ASTERACEAE

ASTERACEAE

ASTERACEAE

ASTERACEAE

ASTERACEAE

ASTERACEAE

ASTERACEAE

ASTERACEAE

ASTERACEAE

BIGNONIACEAE

BORAGINACEAE

BORAGINACEAE

BORAGINACEAE

BORAGINACEAE

BRASSICACEAE

BRASSICACEAE

BRASSICACEAE

BRASSICACEAE

BRASSICACEAE

BRASSICACEAE

BRASSICACEAE

BRASSICACEAE

BRASSICACEAE
Pentzia incana (Thunb.) Kuntze

Pentzia punctata Harv.

Pentzia sphaerocephala DC.

Phymaspermum aciculare (E.Mey. ex Harv.) Benth. \& Hook. ex Jackson

Phymaspermum parvifolium (DC.) Benth. \& Hook. ex Jackson

Pseudognaphalium luteo-album (L.) Hilliard \& B.L.Burtt

Pseudognaphalium undulatum (L.) Hilliard \& B.L.Burtt

Pteronia adenocarpa Harv.

Pteronia erythrochaeta DC.

Pteronia glauca Thunb.

Pteronia incana (Burm.) DC.

Pteronia staehelinoides DC.

Pulicaria scabra (Thunb.) Druce

Rosenia humilis (Less.) Bremer

Schkuhria pinnata (Lam.) Cabr.

Senecio achilleifolius DC.

Senecio acutifolius DC.

Senecio agapetes C.Jeffrey

Senecio asperulus DC.

Senecio burchellii DC.

Senecio erysimoides DC.

K

Senecio incomptus DC.

Senecio juniperinus L.f. var. juniperinus

Senecio lanifer Mart. ex C.Jeffrey

Senecio leptophyllus DC.

Senecio linifolius $\mathrm{L}$.

Senecio oxyodontus DC.

Senecio radicans (L.f.) Sch.Bip.

Senecio ruwenzoriensis S.Moore

Senecio speciosus Willd.

Senecio striatifolius DC.

Senecio vimineus DC.

Sonchus dregeanus DC.

Tarchonanthus camphoratus $\mathrm{L}$.

Tolpis capensis (L.) Sch.Bip.

Tripteris aghillana DC. var. aghillana

Troglophyton capillaceum (Thunb.) Hilliard \& B.L.Burtt

Ursinia montana DC. subsp. apiculata (DC.) Prassler

Ursinia nana DC. subsp. nana

Ursinia paleacea (L.) Moench

Ursinia trifida (Thunb.) N.E.Br. forma trifida

Verbesina encelioides (Cav.) Benth. \& Hook.

Rhigozum obovatum Burch.

Anchusa capensis Thunb.

Ehretia rigida (Thunb.) Druce

Lithospermum cinereum DC.

Lithospermum diversifolium DC.

Boscia oleoides (Burch. ex DC.) Toelken

Cadaba aphylla (Thunb.) Wild

Capsella bursa-pastoris (L.) Medik.

Cardaria draba (L.) Desv.

Descurainia sophia (L.) Webb ex Prantl

Erucastrum strigosum (Thunb.) O.E.Schulz

Heliophila cornuta Sond. var. squamata (Schltr.) Marais

Heliophila suavissima Burch. ex DC.

Lepidium africanum (Burm. f.) DC. subsp. divaricatum (Aiton) Jonsell 
BRASSICACEAE

BRASSICACEAE

BRASSICACEAE

BRASSICACEAE

BUDDLEJACEAE

BUDDLEJACEAE

BUDDLEJACEAE

CAMPANULACEAE

CAMPANULACEAE

CAMPANULACEAE

CAMPANULACEAE

CAMPANULACEAE

CAMPANULACEAE

CAMPANULACEAE

CAMPANULACEAE

CAMPANULACEAE

CAMPANULACEAE

CAMPANULACEAE

CAMPANULACEAE

CARYOPHYLLACEAE

CARYOPHYLLACEAE

CARYOPHYLLACEAE

CARYOPHYLLACEAE

CELASTRACEAE

CELASTRACEAE

CELASTRACEAE

CELASTRACEAE

COMMELINACEAE

COMMELINACEAE

CONVOLVULACEAE

CONVOLVULACEAE

CONVOLVULACEAE

CRASSULACEAE

CRASSULACEAE

CRASSULACEAE

CRASSULACEAE

CRASSULACEAE

CRASSULACEAE

CRASSULACEAE

CRASSULACEAE

CRASSULACEAE

CRASSULACEAE

CRASSULACEAE

CRASSULACEAE

CRASSULACEAE

CRASSULACEAE

CRASSULACEAE

CRASSULACEAE

CRASSULACEAE

CRASSULACEAE

CUCURBITACEAE

CUCURBITACEAE

CUCURBITACEAE

DIPSACACEAE

DIPSACACEAE

EBENACEAE

EBENACEAE
Rorippa fluviatilis (E.Mey. ex Sond.) Thell.

Sisymbrium burchellii DC. var. burchellii

Sisymbrium capense Thunb.

Sisymbrium orientale L.

Buddleja glomerata H.L.Wendl.

Buddleja salviifolia (L.) Lam.

Gomphostigma virgatum (L.f.) Baill.

Cyphia digitata (Thunb.) Willd.

Cyphia sylvatica var. sylvatica Eckl.

Lobelia flaccida subsp. flaccida (C.Presl) A.DC.

Lobelia neglecta Roem. \& Schult.

Wahlenbergia albens (Spreng. ex A.DC.) Lammers

Wahlenbergia androsacea A.DC.

Wahlenbergia galpiniae Schltr.

Wahlenbergia neorigida Lammers

Wahlenbergia nodosa (H.Buek) Lammers

Wahlenbergia pyrophila Lammers

Wahlenbergia uitenhagensis (H.Buek) Lammers

Wahlenbergia undulata (L.f.) A.DC.

Dianthus thunbergii Hooper

Silene undulata Aiton

Stellaria media (L.) Vill.

Stellaria pallida (Dumort.) Piré

Gymnosporia buxifolia (L.) Szyszyl.

Gymnosporia linearis (L.f.) Loes. subsp. linearis

Maytenus polyacantha (Sond.) Marais

Maytenus undata (Thunb.) Blakelock

Commelina africana $\mathrm{L}$.

Cyanotis speciosa (L.f.) Hassk.

Convolvulus sagittatus Thunb.

Cuscuta campestris Yunck.

Ipomoea oenotheroides (L.f.) Raf. ex Hallier f.

Cotyledon campanulata Marloth

Cotyledon orbiculata L. var. oblonga (Haw.) DC.

Us

Cotyledon orbiculata L. var. orbiculata

Cotyledon velutina Hook.f.

Us

Crassula capitella Thunb. subsp. capitella

Crassula capitella Thunb. subsp. thyrsiflora (Thunb.) Toelken

Crassula corallina Thunb.

Crassula dependens Bolus

Crassula exilis Harv. subsp. cooperi (Regel) Toelken

Crassula lanuginosa var. pachystemon Harv.

Us

Crassula mesembryanthoides (Haw.) Dietr.

Crassula muscosa L. var. muscosa

Crassula obovata Haw.

Crassula perforata Thunb.

Crassula pubescens Thunb. subsp. rattrayi (Schönland \& Baker f.) Toelken

Crassula sarcocaulis Eckl. \& Zeyh.

Crassula tetragona L. subsp. acutifolia (Lam.) Toelken

Crassula vaillantii (Willd.) Roth

Cucumis zeyheri Sond.

Kedrostis africana (L.) Cogn.

Kedrostis capensis (Sond.) A.Meeuse

Scabiosa columbaria L.

Scabiosa incisa Mill.

Diospyros austro-africana De Winter

Diospyros lycioides Desf. subsp. lycioides 
EBENACEAE

EBENACEAE

EBENACEAE

ERICACEAE

ERICACEAE

ERICACEAE

ERICACEAE

ERICACEAE

EUPHORBIACEAE

EUPHORBIACEAE

EUPHORBIACEAE

EUPHORBIACEAE

EUPHORBIACEAE

EUPHORBIACEAE

EUPHORBIACEAE

EUPHORBIACEAE

EUPHORBIACEAE

EUPHORBIACEAE

FABACEAE

FABACEAE

FABACEAE

FABACEAE

FABACEAE

FABACEAE

FABACEAE

FABACEAE

FABACEAE

FABACEAE

FABACEAE

FABACEAE

FABACEAE

FABACEAE

FABACEAE

FABACEAE

FABACEAE

FABACEAE

FABACEAE

FABACEAE

FABACEAE

FABACEAE

FABACEAE

FABACEAE

FABACEAE

FABACEAE

FABACEAE

FABACEAE

FABACEAE

FABACEAE

FABACEAE

FABACEAE

FABACEAE

FABACEAE

FABACEAE

GENTIANACEAE

GENTIANACEAE

GERANIACEAE

GERANIACEAE
Diospyros scabrida (Harv. ex Hiern) De Winter

Diospyros whyteana (Hiern) F.White

Euclea crispa (Thunb.) Guerke subsp. ovata (Burch.) F.White

Erica albens L. var. albens

Erica fuscescens (Klotzsch) E.G.H.Oliv.

Erica lanata Andrews

Erica lehmannii Klotzsch

K

Erica leucopelta Tausch

Clutia pulchella L. var. pulchella

Euphorbia aggregata A.Berger var. aggregata

Euphorbia arceuthobioides Boiss.

Euphorbia caterviflora N.E.Br.

Euphorbia clavarioides Boiss. var. clavarioides

Euphorbia mauritanica L. var. mauritanica

Euphorbia micracantha Boiss.

Euphorbia ornithopus Jacq.

Euphorbia polycephala Marloth

K

Euphorbia tridentata Lam.

Acacia caffra (Thunb.) Willd.

Acacia fleckii Schinz

Acacia karroo Hayne

Argyrolobium collinum Eckl. \& Zeyh.

Argyrolobium pauciflorum Eckl. \& Zeyh. var. pauciflorum

Aspalathus acicularis E.Mey. subsp. acicularis

Dichilus gracilis Eckl. \& Zeyh.

Dolichos angustifolius Eckl. \& Zeyh.

Indigofera alpina Eckl. \& Zeyh.

Indigofera alternans DC. var. alternans

Indigofera disticha Eckl. \& Zeyh.

Indigofera mauritanica (L.) Thunb.

Indigofera procumbens $\mathrm{L}$.

Indigofera rhytidocarpa Benth. ex Harv. subsp. rhytidocarpa

Indigofera sessilifolia DC.

Lebeckia macrantha Harv.

Lebeckia spinescens Harv.

Lessertia carnosa Eckl. \& Zeyh. $\quad$ K

Lessertia depressa Harv.

Lessertia frutescens (L.) Goldblatt \& J.C.Manning

Lessertia humilis (E.Phillips \& R.A.Dyer) Goldblatt \& J.C.Manning

Lessertia microphylla (Burch. ex DC.) Goldblatt \& J.C.Manning

Lotononis caerulescens E.Mey.

Lotononis divaricata (Eckl. \& Zeyh.) Benth.

Lotononis laxa Eckl. \& Zeyh.

Lotononis pulchella (E.Mey.) B.-E.van Wyk

Lotononis pumila Eckl. \& Zeyh.

Lotononis pungens Eckl. \& Zeyh.

Medicago laciniata (L.) Mill. var. laciniata

Melolobium candicans (E. Mey.) Eckl. \& Zeyh.

Melolobium microphyllum (L.f.) Eckl. \& Zeyh.

Melolobium obcordatum Harv.

Tephrosia angulata E. Mey.

Tephrosia capensis (Jacq.) Pers.

Trifolium burchellianum Ser. subsp. burchellianum

Chironia jasminoides L.

Sebaea elongata E.Mey.

Geranium harveyi Briq.

Geranium incanum Burm.f. 
GERANIACEAE

GERANIACEAE

GERANIACEAE

GERANIACEAE

GERANIACEAE

GERANIACEAE

GERANIACEAE

GERANIACEAE

GERANIACEAE

GERANIACEAE

GERANIACEAE

GERANIACEAE

GERANIACEAE

GERANIACEAE

GERANIACEAE

GERANIACEAE

GERANIACEAE

GERANIACEAE

GERANIACEAE

GRUBBIACEAE

HALORAGACEAE

KIGGELARIACEAE

LAMIACEAE

LAMIACEAE

LAMIACEAE

LAMIACEAE

LAMIACEAE

LAMIACEAE

LAMIACEAE

LAMIACEAE

LAMIACEAE

LAMIACEAE

LAMIACEAE

LAMIACEAE

LAMIACEAE

LINACEAE

LORANTHACEAE

MALVACEAE

MALVACEAE

MALVACEAE

MALVACEAE

MALVACEAE

MALVACEAE

MALVACEAE

MALVACEAE

MALVACEAE

MALVACEAE

MALVACEAE

MALVACEAE

MALVACEAE

MALVACEAE

MALVACEAE

MELIANTHACEAE
Monsonia emarginata (L.f.) L'Her.

Pelargonium abrotanifolium (L.f.) Jacq.

Pelargonium alchemilloides (L.) L'Her.

Pelargonium aridum R.A.Dyer

Pelargonium cordifolium (Cav.) Curtis

Pelargonium dichondrifolium DC.

Pelargonium glutinosum (Jacq.) L'Her.

Pelargonium grossularioides (L.) L'Her.

Pelargonium minimum (Cav.) Willd.

Pelargonium odoratissimum (L.) L'Her.

Pelargonium quercifolium (L.f.) L'Her.

Pelargonium ramosissimum (Cav.) Willd.

Pelargonium reniforme Curtis

Pelargonium scabrum (L.) L'Her.

Pelargonium sidoides DC.

Pelargonium tragacanthoides Burch.

Pelargonium vitifolium (L.) L'Her.

Pelargonium zonale (L.) L'Hér.

Sarcocaulon camdeboense Moffett

Grubbia rosmarinifolia P.J.Bergius subsp. rosmarinifolia

Gunnera perpensa L.

Kiggelaria africana $\mathrm{L}$.

Ballota africana (L.) Benth.

Becium burchellianum (Benth.) N.E.Br.

Leonotis ocymifolia (Burm.f.) Iwarsson var. ocymifolia

Mentha longifolia (L.) Huds. subsp. capensis (Thunb.) Briq.

Salvia repens Burch. ex Benth. var. repens

Salvia stenophylla Burch. ex Benth.

Salvia verbenaca $\mathrm{L}$.

Stachys aethiopica $\mathrm{L}$.

Stachys cymbalaria Briq.

Stachys dregeana Benth.

Stachys linearis Burch. ex Benth.

Stachys rugosa Aiton

Teucrium africanum Thunb.

Linum thunbergii Eckl. \& Zeyh.

Moquiniella rubra (A.Spreng.) Balle

Abutilon sonneratianum (Cav.) Sweet

Grewia occidentalis L. subsp. occidentalis

Grewia robusta Burch.

Hermannia coccocarpa (Eckl. \& Zeyh.) Kuntze

Hermannia cuneifolia Jacq. var. cuneifolia

Hermannia cuneifolia Jacq. var. glabrescens (Harv.) I.Verd.

Hermannia filifolia L.f. var. filifolia

Hermannia glabrata L.f.

Hermannia linearifolia Harv.

Hermannia vestita Thunb.

Hibiscus aethiopicus $\mathrm{L}$.

Hibiscus pusillus Thunb.

Hibiscus trionum L.

Malva neglecta Wallr.

Malva parviflora var. parviflora $\mathrm{L}$.

Melianthus comosus Vahl
MESEMBRYANTHEMACEAE

MESEMBRYANTHEMACEAE

MESEMBRYANTHEMACEAE
Chasmatophyllum musculinum Haw.) Dinter \& Schwantes

Delosperma brevisepalum L.Bolus var. brevisepalum

Delosperma congestum L.Bolus 
MESEMBRYANTHEMACEAE MESEMBRYANTHEMACEAE MESEMBRYANTHEMACEAE MESEMBRYANTHEMACEAE MESEMBRYANTHEMACEAE MESEMBRYANTHEMACEAE MESEMBRYANTHEMACEAE MESEMBRYANTHEMACEAE MESEMBRYANTHEMACEAE MESEMBRYANTHEMACEAE MESEMBRYANTHEMACEAE MESEMBRYANTHEMACEAE MESEMBRYANTHEMACEAE MESEMBRYANTHEMACEAE MESEMBRYANTHEMACEAE MESEMBRYANTHEMACEAE MESEMBRYANTHEMACEAE MESEMBRYANTHEMACEAE MESEMBRYANTHEMACEAE MOLLUGINACEAE MOLLUGINACEAE MOLLUGINACEAE MYRSINACEAE MYRSINACEAE NYCTAGINACEAE OLEACEAE OROBANCHACEAE OXALIDACEAE OXALIDACEAE OXALIDACEAE OXALIDACEAE OXALIDACEAE PAPAVERACEAE PAPAVERACEAE PEDALIACEAE PEDALIACEAE PENAEACEAE PENAEACEAE PLANTAGINACEAE POLYGALACEAE POLYGALACEAE POLYGALACEAE POLYGALACEAE POLYGALACEAE POLYGALACEAE POLYGONACEAE POLYGONACEAE PORTULACACEAE RANUNCULACEAE RANUNCULACEAE RANUNCULACEAE RHAMNACEAE ROSACEAE RUBIACEAE RUBIACEAE RUBIACEAE
Delosperma floribundum L.Bolus

Delosperma frutescens L. Bolus

Delosperma gramineum L.Bolus

Delosperma subincanum (Haw.) Schwantes

Drosanthemum hispidum (L.) Schwantes

Drosanthemum jamesii L.Bolus

Eberlanzia cradockensis (Kuntze) Schwantes

Eberlanzia ferox (L.Bolus) L.Bolus

Malephora crocea (Jacq.) Schwantes var. crocea

Mestoklema elatum N.E.Br. ex Glen

Phyllobolus splendens (L.) Gerbaulet subsp. splendens

Psilocaulon coriarium (Burch. ex N.E.Br.) N.E.Br.

Psilocaulon junceum (Haw.) Schwantes

Psilocaulon liebenbergii L.Bolus

Ruschia unidens (Haw.) Schwantes

Ruschia utilis (L.Bolus) L.Bolus var. giftbergensis L.Bolus

Trichodiadema barbatum (L.) Schwantes

Trichodiadema pygmaeum L.Bolus

$\mathrm{R}$

Trichodiadema strumosum (Haw.) L.Bolus

Hypertelis salsoloides (Burch.) Adamson var. salsoloides

Limeum aethiopicum Burm. subsp. aethiopicum

Pharnaceum trigonum Eck1. \& Zeyh.

Myrsine africana $\mathrm{L}$.

Rapanea melanophloeos (L.) Mez

Boerhavia erecta $\mathrm{L}$.

Olea europaea (L.) subsp. africana (Mill.) P.S.Green

Hyobanche sanguinea L.

Oxalis bifurca Sond. var. angustiloba Lodd.

Oxalis bifurca Lodd. var. bifurca

Oxalis depressa Eckl. \& Zeyh.

Oxalis stellata Eckl. \& Zeyh. var. stellata

Oxalis stenopetala T.M.Salter

Argemone ochroleuca Sweet subsp. ochroleuca

Papaver aculeatum Thunb.

Pterodiscus luridus Hook.f.

Sesamum capense Burm.f.

Penaea acutifolia A.Juss.

Penaea cneorum Meerb. subsp. gigantea R.Dahlgren

Plantago lanceolata L.

Muraltia macrocarpa Eckl. \& Zeyh.

Polygala ericaefolia DC.

Polygala garcinii DC.

Polygala leptophylla Burch. var. leptophylla

Polygala uncinata E.Mey. ex Meisn.

Polygala virgata Thunb. var. virgata

Polygonum aviculare L.

Rumex lanceolatus Thunb.

Anacampseros arachnoides (Haw.) Sims

Clematis brachiata Thunb.

Ranunculus multifidus Forssk.

Thalictrum minus L.

Rhamnus prinoides L'Her.

Leucosidea sericea Eckl. \& Zeyh.

Anthospermum rigidum Eckl. \& Zeyh. subsp. rigidum

Galium capense Thunb. subsp. capense

Galium tomentosum Thunb. 
RUBIACEAE

RUBIACEAE

SALICACEAE

SALICACEAE

SANTALACEAE

SAPINDACEAE

SCROPHULARIACEAE

SCROPHULARIACEAE

SCROPHULARIACEAE

SCROPHULARIACEAE

SCROPHULARIACEAE

SCROPHULARIACEAE

SCROPHULARIACEAE

SCROPHULARIACEAE

SCROPHULARIACEAE

SCROPHULARIACEAE

SCROPHULARIACEAE

SCROPHULARIACEAE

SCROPHULARIACEAE

SCROPHULARIACEAE

SCROPHULARIACEAE

SCROPHULARIACEAE

SCROPHULARIACEAE

SCROPHULARIACEAE

SCROPHULARIACEAE

SCROPHULARIACEAE

SCROPHULARIACEAE

SCROPHULARIACEAE

SCROPHULARIACEAE

SCROPHULARIACEAE

SCROPHULARIACEAE

SCROPHULARIACEAE

SCROPHULARIACEAE

SCROPHULARIACEAE

SCROPHULARIACEAE

SCROPHULARIACEAE

SOLANACEAE

SOLANACEAE

SOLANACEAE

SOLANACEAE

SOLANACEAE

SOLANACEAE

SOLANACEAE

SOLANACEAE

SOLANACEAE

SOLANACEAE

SOLANACEAE

SOLANACEAE

THYMELAEACEAE

THYMELAEACEAE

THYMELAEACEAE

URTICACEAE

URTICACEAE

VERBENACEAE

VERBENACEAE

VERBENACEAE
Nenax microphylla (Sond.) T.M.Salter

Rubia petiolaris DC.

Populus alba L. var. alba

Salix mucronata Thunb. subsp. capensis (Thunb.) Immelman

Thesium galioides A.DC.

Dodonaea angustifolia L.f.

Aptosimum procumbens (Lehm.) Steud. var. elongatum (Hiern) Codd

Aptosimum procumbens (Lehm.) Steud. var. procumbens

Diascia capsularis Benth.

Diascia integerrima Benth.

Us

Hebenstretia dura Choisy

Jamesbrittenia atropurpurea (Benth.) Hilliard

Jamesbrittenia aurantiaca (Burch.) Hilliard

Jamesbrittenia crassicaulis (Benth.) Hilliard

Jamesbrittenia filicaulis (Benth.) Hilliard

Jamesbrittenia fruticosa (Benth.) Hilliard

Jamesbrittenia pinnatifida (L.f.) Hilliard

Jamesbrittenia tysonii (Hiern) Hilliard

Limosella grandiflora Benth.

Manulea crassifolia Benth. subsp. crassifolia

Nemesia affinis Benth.

Nemesia albiflora N.E.Br.

Nemesia fruticans (Thunb.) Benth.

Us

Selago albida Choisy

Selago corymbosa L.

Selago divaricata L.f.

Selago dolosa Hilliard

Selago geniculata L.f.

Selago paniculata Thunb.

Selago saxatilis E.Mey.

Selago speciosa Rolfe

Selago zeyheri Rolfe

Sutera halimifolia (Benth.) Kuntze

Sutera laxiflora (Benth.) Kuntze

Sutera mollis (Benth.) Hiern

Veronica anagallis-aquatica $\mathrm{L}$.

Datura stramonium L.

Lycium cinereum Thunb.

Lycium ferocissimum Miers

Lycium oxycarpum Dunal

Lycium prunus-spinosa Dunal

Lycium schizocalyx C.H.Wright

Nicotiana glauca Graham

Solanum capense L.

Solanum nigrum $\mathrm{L}$.

Solanum retroflexum Dunal

Solanum tomentosum L.

Withania somnifera (L.) Dunal

Gnidia microphylla Meisn.

Gnidia polycephala (C.A.Mey.) Gilg

Passerina obtusifolia Thoday

Urtica dioica $\mathrm{L}$.

Urtica urens $\mathrm{L}$.

Chascanum pinnatifidum (L.f.) E.Mey var. pinnatifidum.

Lantana rugosa Thunb.

Lippia javanica (Burm.f.) Spreng. 
VERBENACEAE

VISCACEAE

VISCACEAE

VITACEAE

VITACEAE

ZYGOPHYLLACEAE

ZYGOPHYLLACEAE
Verbena tenuisecta Briq.

Viscum continuum E.Mey. ex Sprague

Viscum rotundifolium L.f.

Cyphostemma quinatum (Dryand.) Desc. ex Wild \& R.B.Drumm.

Rhoicissus tridentata (L.f.) Wild \& R.B.Drumm.

Tribulus terrestris L.

Zygophyllum incrustatum E.Mey. ex Sond.
Complete list

Total species:

Total genera:

Total families:

Total red data species:
Selective list

680

333

87

13
Total species:

Total genera:

Total families:

Total red data species:
479

227

62

8 
